\title{
Assessing risks of returning mined land to grazing in the Bowen Basin of central Queensland, Australia
}

\author{
R.I. Maczkowiack Centre for Mined Land Rehabilitation; and School of Integrative Systems, The \\ University of Queensland, Australia
}

C.S. Smith School of Integrative Systems, The University of Queensland, Australia

G.J. Slaughter School of Accounting, Economics and Finance, University of Southern Queensland, Australia

D.R. Mulligan Centre for Mined Land Rehabilitation, The University of Queensland, Australia

D.C. Cameron School of Integrative Systems, The University of Queensland, Australia

\begin{abstract}
Regulation of mining in Queensland, Australia requires completed rehabilitation to result in the site being safe, stable, presenting no adverse off-site impacts and for a sustainable end use acceptable to stakeholders to be designated. By 2008, an estimated area of 70,000 ha of the coal-mining region of central Queensland had been disturbed by mining activities of which some one third has been rehabilitated. The remaining notional accrued rehabilitation liability exceeds $A \$ 1$ billion.

Rehabilitation of mined land in central Queensland is performed by re-contouring spoil heaps to reduce slope angles, applying a layer of topsoil, and planting various combinations of pasture grasses, shrubs and trees. Approximately half of the rehabilitated areas have been revegetated using bushland species native to the region and half to exotic pasture species suited to cattle grazing. Vegetation cover is valuable in protecting the soil surface from the erosive forces of the often-intense summer rains that occur in the region. Where pasture productivity is high, there is sufficient vegetation both to protect the soil surface and to support grazing. This outcome has been demonstrated both theoretically and in small-scale trials. However, inappropriate grazing management (overgrazing) may reduce the amount of vegetation cover below that needed to protect the soil. The style of land management practised by the manager of the cattle is therefore critical to the sustainability of grazing as an end use.
\end{abstract}

This paper reports on research into the management style likely to be used by the region's graziers if granted tenure of mined land. Graziers' management style was modelled as being influenced by their characteristics and circumstances. The chief influences were found to be:

- The financial stability of the grazier's business (25\%).

- The effect of interventions that a company may take; for example, building respectful, trusting relationships with graziers (23\%).

- Graziers' non-financial motives in seeking tenure of mined land (17\%).

- Graziers' underlying rural values and attitudes to land management (14\%).

- The property's operational flexibility (12\%).

- $\quad$ The external climatic and economic environment (9\%).

An understanding of factors that influence the grazing management of mined land can be used to assess risks, suggest interventions to reduce grazing risks, to guide the planning of future rehabilitation work, and to support a company's end use proposal to the regulator. 


\section{Introduction}

Best practice principles for mine closure have in recent years recognised the need to include integration of closure plans with life of mine planning, effective consultation with stakeholders, and the use of a risk-based approach to reduce cost and uncertainty (ANZMEC/MCA, 2000; Cobby, 2007; Finucane, 2008). In the early stages of the planning process, closure principles are developed around a broad evaluation of alternative configurations of the post-mining landforms and, over time, become focussed on increasingly specific aspects. Although best practice closure principles are now widely recognised, Welsh (2007) observes: 'Only in the last few years has there been a more formal approach to mine closure planning involving processes such as the evaluation of post-mining land use options, closure action plans, risk assessment, third-party cost estimation, stakeholder consultation, and the use of sustainability assessment tools'.

Some progress has been made in the areas identified by Welsh (2007). For instance, Logan et al. (2007), describe an assessment technique based on multi-criteria analysis, in which alternative closure configurations are scored on a set of weighted criteria. Applications of the multi-criteria approach to particular sites in central Queensland have been described by Grimshaw (2007) and Welsh et al. (2007).

Under Queensland legislation, coal mining companies are required to restore disturbed land to a sustainable end use acceptable to stakeholders (EPA, 2006). On domains of open cut mined land in the Bowen Basin that support productive pasture, the return of the land to local farmers for cattle grazing is an end use implicit in the legislation under which the mines were commenced (The State of Queensland, 1968). Grazing as an end use is likely to be accepted by the regulator because it restores the site's previous land use (EPA, 2006), and grazing is 'widely regarded across the stakeholder representatives as an acceptable post-mining land use and a positive rehabilitation objective' (Grigg et al., 2004). However, every end use is accompanied by various threats to its sustainability. Therefore, there is a need for a credible method by which to assess the sustainability of grazing.

This paper outlines a formal approach to evaluation of grazing as a post-mining land use option. An assessment tool is developed that evaluates threats to the sustainability of grazing where responsibility for land management is transferred to local farmers as future custodians of the site. The model is applicable in end use decision-making for domains where rehabilitation has already been completed. It is also useful in guiding the planning of future rehabilitation work. The model is updateable over time. The method could be applied to the risk assessment of alternative end uses when structured and informed by appropriate data. The approach could also be applied and adapted to fit the local circumstances of other regions where the relinquishment of land to a subsequent end use is planned.

The paper commences by paraphrasing the requirements of state legislation and the role of companies' own environmental policies. This is followed by a description of the natural environment of the target region, and of rehabilitation outcomes being achieved. Outcomes include domains whose resulting ecosystem is a dense monoculture of an exotic pasture species, Buffel grass. The vegetation cover provided by Buffel grass protects the soil surface the erosive effects of rainfall, but is itself highly susceptible to fire and vulnerability to water erosion. Grazing as a means to reduce risks of fire is therefore considered for such sites. The capacity of productive sites to support grazing has been demonstrated both theoretically and practically. However, grazing introduces a new threat - the possibility that the land may be over-grazed. Over-grazing too may render a site susceptible to water erosion. The management style (the grazier's propensity to manage the land conservatively and sensitively) therefore emerges as a threat to sustainability of grazing. This paper focuses on understanding the factors that drive graziers' management styles and predicts their outcomes.

\subsection{Imperatives to restore land to a sustainable use acceptable to stakeholders}

Mining companies are strongly motivated, both legislatively and by their own environment policies, to rehabilitate disturbed land. The performance of rehabilitation necessarily lags behind the rate of disturbance, and during periods of expansion of mining activity results in increasing aggregate liabilities. Costs of rehabilitation in 2001 were approximately $\mathrm{A} \$ 19,000$ per ha, resulting in annual liabilities of $\mathrm{A} \$ 50,000$ and an accrued liability until then of about A $\$ 1$ billion (Williams, 2001). The research described in this paper develops a tool with which to understand and predict sustainability where grazing is contemplated as the end use. Two factors that influence a company's choice of end use are now described. 


\subsubsection{Legal guidelines regarding choice of end use for domains of solid mine waste}

Under Queensland law (The State of Queensland, 1968, 1989, 1994) and related regulations, companies are required to make mined sites safe, to ensure there are no adverse off-site impacts (e.g. toxic drainage), and to ensure that the site is physically stable. The company must also nominate an end use for each post-mining domain, demonstrate that the nominated use is acceptable to stakeholders, and that it is sustainable. Were an end use to prove unsustainable, the company may incur financial penalties (non-return of security deposits). Furthermore, loss of a company's reputation with both the regulator and the public would compromise their 'social license to operate in new areas' (Fleury and Copley, 2008). Stakeholder ownership of closure plans is an effective means to enhance the sustainability of the chosen end use, and hence the company's social license to operate. There is therefore a desire to better understand sources of risk associated with future custodianship of the mined land.

The Queensland regulator requires that completed mine site rehabilitation be formally certified as complying with the undertakings given and agreed to when the authority to mine the site was originally granted. The regulator encourages rehabilitation to be performed on a progressive basis during the life of the mine, and in 2006 released guidelines to assist companies in the planning of their rehabilitation work (EPA, 2006). The guidelines rank rehabilitation goals, objectives, criteria, and end uses in a hierarchy of preferred outcomes.

To ensure that the mine fulfils its responsibilities, the rehabilitation objectives must:

- Address potential environmental impacts.

- Achieve the highest practicable level in a hierarchy of rehabilitation outcomes.

- Identify post-mining land uses that are acceptable to the community, local government and any other relevant stakeholders.

The aim is to achieve a high-level end use that is environmentally sustainable. A hierarchy of rehabilitation goals delineated by the Queensland regulator in descending order of acceptability is (EPA, 2006):

- Level 1: Avoid disturbance that would require rehabilitation.

- Level 2: Reinstate the ecosystem that existed prior to European settlement.

- Level 3: Develop an alternative outcome with a higher economic value than the previous land use.

- Level 4: Reinstate the site's former land use (grazing in this case). This option has wide appeal, and is the focus of the research reported here.

- Level 5: Achieve a use with reduced environmental, economic or social values.

- Level 6: Achieve an unusable contaminated site that is not adequately managed.

The hierarchy applies both to rehabilitation already completed and to future rehabilitation work. Queensland regulations also provide for completed rehabilitation to be certified progressively prior to final mine closure.

\subsubsection{Consistency with company policy}

In addition to regulatory mandates, mining companies are themselves strongly motivated by societal opinion to minimise environmental harm. To this end, leading companies have subscribed to industry standards and commitments regarding closure (ANZMEC/MCA, 2000; ICMM, 2008), as well as publishing their own company-specific, publicly available environmental policy statements (e.g. Rio Tinto, 2004; Thiess Pty Ltd, 2005; BHP Billiton, 2008; Xstrata, 2008). Companies strive to match actual performance with their environmental policy rhetoric and may issue publicly available annual reports on their environmental performance, e.g. BHP Billiton and Rio Tinto sustainability reports for recent years (BHP Billiton, 2009; Coal and Allied, 2009). While companies seek to minimise harm to the environment, the environmental disturbance caused by open cut mining is never minimal. In the Bowen Basin, a company's rehabilitation efforts are particularly difficult because the natural environment is challenging. Therefore, very significant efforts are required to return a site to its prior use, or to any of the preferred, higher level outcomes. 


\subsection{The need for a decision support tool}

Closure planning should be an integral part of overall mine planning (Finucane, 2008), and is therefore integral with the mine's feasibility stage. Early planning should then be followed by periodic audits of environmental performance that ask questions concerning the efficacy of current rehabilitation operations as preparation for the post-mining land use (Department of the Environment, 1996). Early identification of rehabilitation goals would permit resources to be directed to their efficient attainment. There is therefore a need for an objective tool with which to evaluate the risks associated with the sustainability of various specific end uses.

There is also a need for such a tool at sites where rehabilitation has proceeded where no binding legal obligation or company undertaking to achieve any specific end use exists - where a decision regarding choice of end use has been deferred, dependent on the success of outcomes. In those cases, where outcomes are now evident, the sustainability of grazing could be assessed with a view to progressive certification.

This study identifies threats to the sustainability of cattle grazing as an end use for mined land of the region.

\subsection{The natural environment of the Bowen Basin}

\subsubsection{Soils}

The parts of the Bowen Basin being mined are of predominantly two soil types, both readily erodable (NRM, 2004):

- Sodosols - highly dispersive saline, solodised sand over clay. This soil type is known locally by the native vegetation it supports as 'forest country'. Where these soils occur in hilly land, exposed ridges are heavily eroded, exposing underlying rocks. River flats that consist of alluvial duplex-soil sediment are more productive, in part because they are periodically flooded.

- Vertosols - heavy, deep, self-mulching cracking black clays known as Brigalow soils occur only on flatter landscapes.

Areas disturbed by mining include both soil types. Due to the poor aggregation structure of the soil particles, and their sodic nature, sodosols are highly susceptible to water erosion (NRM, 2004). When overlaid on a post-mining landform of material that is often highly dispersive, and at gradients greater than those existing in the natural state, the propensity to erode is heightened.

The soil particles of vertosols are more aggregated, but can be structurally unstable due to raindrop impact, rapid wetting, and frequently produce readily detachable and transportable soil particles, resulting in high soil erodability (NRM, 2004). They are at risk also because of the comparatively shallow depth of topsoil replacement, the underlying spoil properties, the slope angles of the reconstructed landforms, and the possibility of local subsidence areas that add to the number of initiation points for erosion.

\subsubsection{The region's climate}

The mainly summer rain of the region typically consists of erratic, high intensity events. Average annual rainfall is approximately $700 \mathrm{~mm}$. More than $60 \%$ of all mean monthly precipitation occurs in falls of greater than $50 \mathrm{~mm}$ per day. Maximum daily rainfall over the past 100 years vary from 80 to $182 \mathrm{~mm}$ and maximum monthly rainfalls from 130 to $550 \mathrm{~mm}$ (Bureau of Meteorology, 2009). Where flooding rains occur on undisturbed land, there is little risk of erosion, but on a reconstructed landscape, that inevitably contains slopes of much greater than $1 \%$, risks of erosion are high.

\subsubsection{The region's prior land use}

Most of the areas disturbed by open cut mining were previously used for the extensive grazing of cattle. Favoured areas (Brigalow soils) may support cattle at a stocking rate of one adult livestock equivalent (AE) to $2.5 \mathrm{ha}$, while the stocking rate on hilly duplex soils may be as low as one AE to 10 ha. Some areas of Brigalow soils in the region are used for cereal cropping. Legislation (Agreement Acts and EPA guidelines) requires that the region's prior land use be a consideration when choosing a site's end use. 


\subsubsection{The extent of the areas involved}

It is estimated that by $2008,70,000$ ha of land had been disturbed by open cut coal mining in the Bowen Basin (an estimate based on various sources (The State of Queensland, 1999; Grigg, 2001; The State of Queensland, 2003, 2007)). The proportion of rehabilitated land is approximately one third of the areas disturbed. Of the rehabilitated areas, half was revegetated with the pasture species typically used in the region, together with shrub and tree species. The pastured areas are those most suited to grazing as an end use. Remaining areas are revegetated to native species.

\subsubsection{Determinants of rehabilitation outcomes}

Biophysical outcomes of rehabilitation depend on three broad factors: the amount and nature of available topsoil, the rehabilitation technique used, and the climatic conditions at the time of performing the rehabilitation work.

For some domains at a number of mines, and for varying reasons, there is a topsoil deficit. Where this is the case, the productivity of resulting pastures is generally too low to provide adequate cover for protection from erosive rain and grazing cannot be considered. In Brigalow areas, the inherent fertility of the soil increases the likelihood of dense, productive vegetation growth. The structure of Brigalow soils also provides a greater measure of resistance to water erosion than that of the duplex soils, a lower percentage of vegetation cover being required for protection, and steeper gradients can be tolerated.

Details of rehabilitation techniques may vary from site to site, even when managed by the same company (Welsh et al., 2007). The first stage of the rehabilitation process is to re-contour by bulldozer any steep ridges left by dragline machinery. Valleys may be backfilled by dump truck with pre-strip spoil. Specifications of slope angles may vary from site to site. The surface is then prepared for revegetation. Differences in site preparation include whether or not deep-ripping is conducted, whether contour banks are installed, and whether fertiliser is applied. The species of vegetation sown also varies. There may be a focus on native species, grasses, trees or shrubs, or directed towards exotic pasture species preferred for cattle production. Reasons for various rehabilitation techniques relate in part to differing physical conditions, but are also influenced by the mine's history of ownership and the inclinations of the mine's incumbent management and environment officers.

Given the high seasonal variability of rainfall, there will inevitably be some years where even the best of rehabilitation processes prove unsuccessful. Nonetheless, even domains whose initial revegetation programme appeared unsuccessful become progressively colonised by various species. Natural colonisation occurs through seed existing in the applied topsoil. Whether deliberately sown or not, an exotic, naturalised pasture species, Buffel grass (Cenchrus ciliaris) is ubiquitous in the region and on rehabilitated mine sites.

\subsubsection{Outcomes being achieved}

Buffel grass thrives on disturbed sites (Friedel et al., 2006), and despite its tussock growth habit and small basal area, its prolific growth commonly results in $100 \%$ projective cover being achieved. When ungrazed, Buffel grass may accumulate a bulk of dry foliage exceeding $20 \mathrm{t}$ per ha (Grigg, 2001)) that may form a dense blanket of moribund vegetation over the soil surface. Thus, it is capable of providing a high level of protection to the soil from water erosion. However, when dry, it is highly flammable, and constitutes an extreme fire hazard, because a fire, perhaps started by lightning strike, could leave a site highly exposed (with commonly less than $10 \%$ basal area of the plants) and extremely vulnerable to water erosion. An unmanaged monoculture of Buffel grass thus constitutes a significant threat to soil stability (Friedel et al., 2006). However, since Buffel grass is a valued pasture species, a mitigating strategy would be to use cattle to reduce the bulk of plant material. Permitting cattle to graze rehabilitated mine land would also dovetail with local graziers' preference for grazing as a post-mining land use (Grigg et al., 2004), rather than allowing it to simply revert to bushland.

The capacity of selected sites of the region to sustain grazing has been demonstrated both theoretically and in small-scale practical trials (Grigg et al., 2006). However, the sustainability of grazing depends not only on a site's biophysical capability, but also on the manner in which the mined land would be managed. If mined land is used for grazing, it is envisaged that tenure of suitable domains of mined land would revert to a mine's perimeter landholders, who would become responsible for its ongoing management. The source of 
perceived risk is that graziers may allow their cattle to graze the land too heavily, reducing vegetation cover below that needed to resist erosion. The kind of land management used by the grazier is therefore a critical component of grazing risks. It would therefore be helpful to understand the factors that lie behind or drive the land management style of graziers. These drivers are postulated in this research to be graziers' characteristics and circumstances and are the focus of interest.

\subsubsection{Summary}

The foregoing has described the legal and environmental contexts in which biophysical outcomes capable of supporting grazing as a post-mining land use are achieved at some sites. The risk assessment model described in this paper can be used to guide rehabilitation planning and support decisions on whether or not to designate grazing as an end use for those sites.

\section{Methodology}

\subsection{Conceptualising the task}

The research explored the way graziers of the Bowen Basin approach issues of land management, and produced a model to underpin decisions concerning the possible return of rehabilitated mine land of the region to cattle grazing. By identifying and better understanding the factors that influence graziers' current land management practices, and by predicting their influence over future management of rehabilitated mine land, companies can assess the risks of proposing grazing as an end use of existing rehabilitated domains. Company decisions concerning the goals of future rehabilitation work can also be informed by the model. The overall direction of the study was to develop a decision support model that incorporates the characteristics and circumstances of graziers with site-specific biophysical factors so that mining companies can make informed decisions concerning the risks of returning rehabilitated mine land to grazing.

Factors modelled as influencing graziers' land management styles were initially defined broadly as their 'characteristics and circumstances'. The broad description was then refined to selected sets of factors: graziers' business circumstances, their within-person characteristics (values and attitudes), and the external climatic and economic environment. Data were obtained that inform the current status of the selected sets of factors among the region's graziers. These data, the model's prior probabilities, were obtained from stakeholder graziers and mine personnel. Relationships between the motivational drivers and consequent land management style were then ascertained using a technique of expert opinion. The project's focus is thus on the role of graziers' characteristics and circumstances in shaping their land management behaviour.

Commitment by the site's future custodians, to the company's post-closure goals is also a key element in securing sustainability of a site's end use (Robertson and Shaw, 2006; Fleury and Copley, 2008). Strategic actions that build stakeholder commitment are therefore identified as productive steps that companies could take to improve the likelihood of sites being managed sustainably in the long term.

\subsection{The modelling framework}

The research used a Bayesian Belief Network (BBN) as its modelling framework. A BBN consists of a graphical structure that explicitly represents cause-and-effect assumptions. Causes and outcomes are linked via a probabilistic description of the relationships existing between the variables. The causal chain, linking risk drivers to outcomes, is factored as an articulated series of conditional relationships. Probabilistic functions describing the relationships allow key mechanisms to be represented without the full complexity or information needs of a highly reductionist model. The characteristics of a BBN are particularly suited to the research constraints applicable to the Bowen Basin situation. Constraints include inherent uncertainty concerning the relationships between causes and effects, a small sample size, and the availability for some factors of only imprecise qualitative data, sourced from a variety of disciplines. The model improves understanding of the threats to sustainability of grazing, firstly by depicting the cause and effect relationships. Secondly, the model generates predictions of management style under various scenarios. Finally, the model quantifies the sensitivity of management style to the various drivers, and to the riskreducing interventions that mining companies may choose to exercise. 


\subsection{Research methods}

Data were obtained from graziers and mine personnel using a prepared questionnaire conducted at a personal level, supplemented by semi-structured interview questions. The data sought was multi-disciplinary in nature and, depending on the respondent, varied in specificity supplied. Sample sizes were unavoidably small due to the number of mine sites operated by the participating company (seven), and the number of grazier stakeholders whose grazing operations were affected by mining operations (approximately 25 graziers). Nonetheless, the participation rate was high $(100 \%$ of the mines' environment officers) and approximately $85 \%$ of the affected graziers.

Relationships between identified risk drivers and consequent land management style were informed using a process of expert opinion elicitation. The questionnaire instrument used with experts ascertained their probabilistic estimate of the influence on land management outcomes of individual drivers of behaviour. The nineteen experts consulted were of three categories: research academics, agricultural advisors, and graziers. The model's output, the likelihood of the land management style being conservative and sensitive, was then evaluated under various scenarios of the drivers.

\section{$3 \quad$ Model structure}

The model's structure was developed and iteratively refined based on exploratory research and the collected data. Stakeholder data were used to guide the model's structure and to populate it with prior probabilities. Six broad sources of risk were structured as modules with their sub-components as described:

- Module One: The biophysical capability, practicality and commercial attractiveness of grazing the domain.

This module firstly models the site's biophysical capability and hence its safe carrying capacity, using an equation developed by Grigg et al. (2006). The equation incorporates factors affecting the water availability for plants, plant basal area, and affecting nutrient availability. The second aspect brought to account in module one is the commercial attractiveness of the site. Factors of importance identified here were the number of stock that can be supported (a function of pasture productivity and domain size), and any additional 'costs and hassles' that may impede efficient livestock management. Module one output thus expresses the likelihood of a site being biophysically qualified and its attractiveness as a commercial opportunity.

- Module Two: The grazier's values, and attitudes to intensity of land management.

Two components of within-person factors were modelled. Firstly, graziers' intrinsic farming values were categorised as being one of three types: lifestyle, economics or conservation. These were measured using questionnaire items developed by Maybery et al. (2005). Grazier attitudes (or approaches) to stocking intensity were ascertained using questionnaire items developed by Slaughter (2002). Estimates of the influence of values and attitudes on the intensity of stocking graziers practise were obtained using expert opinion.

- Module Three: The capital structure of the grazier's business.

Financial stability of the business is noted in the research literature as a consistent theme associated with farmers' land management decisions. Component factors of financial stability modelled here were: equity level, property size, and the number of households dependent on profits from the business for their livelihood. The three drivers were modelled as influencing the intensity of land use (stocking rate) that graziers employ.

- Module Four: The operational structure of the grazier's business.

This module represents two aspects. That first factor is flexibility of operation - the ability of the farmer to move stock onto or off the property in response to seasonal conditions. Three elements used as indicators of flexibility were: ownership of additional jointly-run properties, operation of a feedlot, and where stock are bought and sold in response to available pasture fodder (rather than running a breeding herd of relatively fixed size). The second element was the pattern stocking intensity typically practised — the family's traditional, stocking pattern. Most properties have been held by the grazier's family for several generations, 
so it is possible to extend the notion of the grazing intensity beyond the current generation to the next. The two components of operational flexibility were then modelled as influencing the intensity of land use.

- Module Five: The external climatic and economic environment in which the grazier's business operates.

This set of factors potentially affects the financial stability of a business. Unlike the factors in module three, the external environment cannot be controlled, but provides the framework in which graziers operate. Key components of the external environment applicable to agricultural production are: The beef industry's terms of trade, occurrence of drought, and the national economy's interest rate levels. These components were therefore modelled as influencing the intensity of land use that graziers were likely to use.

- An Intermediate Node: The influence of the four preceding sets of characteristics and circumstances (modules two, three, four and five) are combined in this node. This node indicates the net influence of the modelled behavioural drivers on a grazier's current land management style.

- Module Six: The long-term relationship commitment by the grazier to the miner's rehabilitation objectives.

Module six represents the likelihood that, having custody of mined land, a grazier would remain committed in the long-term to using the land for grazing in a sustainable manner. Component factors modelled include: graziers' ownership of the closure planning process, whether graziers feel they are consulted adequately regarding compliance provisions of the tenure arrangement, and whether the grazier feels non-financial motives (affective reasons) for seeking tenure of mined land. Where graziers feel strongly committed voluntarily, there is less reliance on coercive provisions of a tenure deed to ensure that an appropriate management style is practised.

- Final output Node: The model's final node represents the likelihood of the grazier's land management style being conservative and sensitive. Its output assumes the pre-requisite of the site qualifying biophysically and commercially (module one). The node's parent drivers are the management style currently practised (expressed in the intermediate node) and commitment (module six). A high probability of a conservative and sensitive management style corresponds to a low risk of environmental degradation.

The combined structure of the various modules and aggregating nodes is shown schematically in Figure 1. Within each module, component factors exert their influence probabilistically on graziers' predicted management style ultimately represented in the final output node.

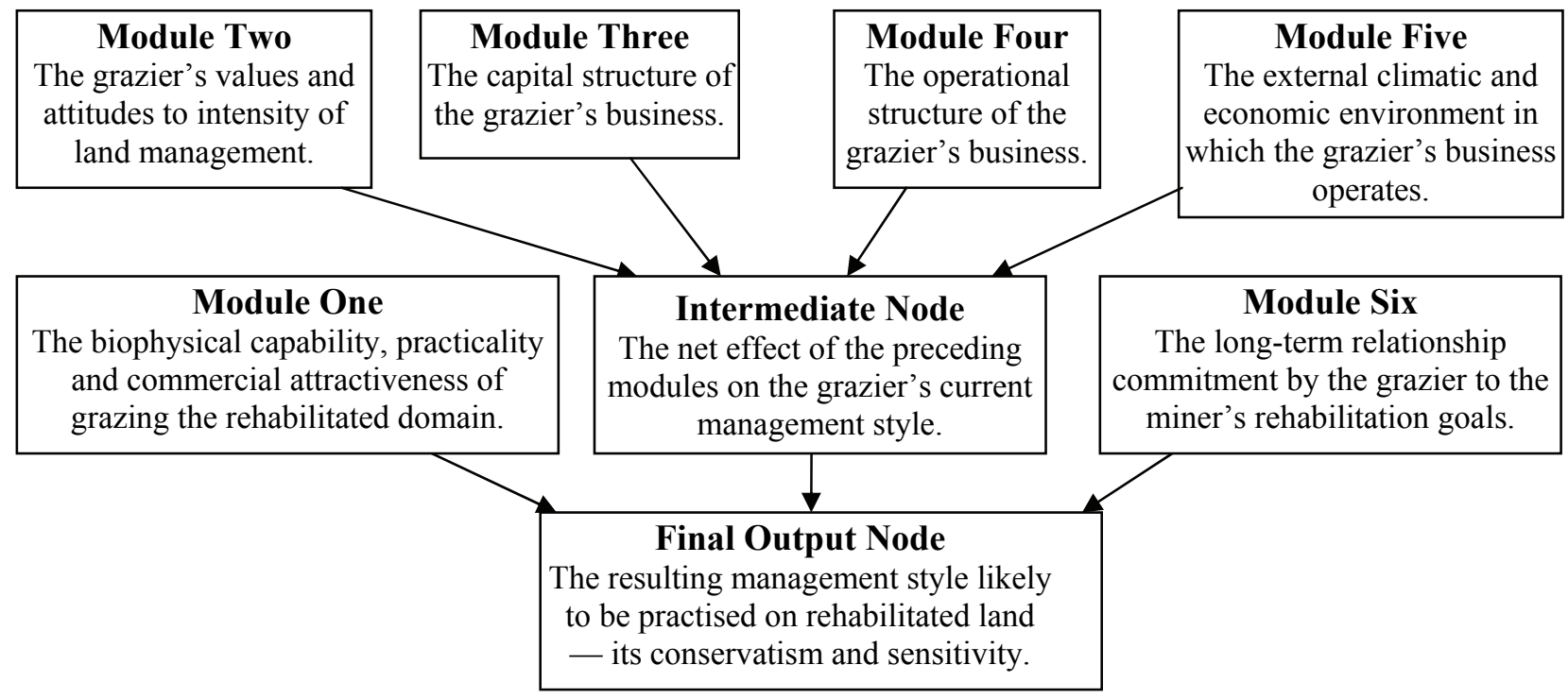

\section{Figure 1 A schematic diagram of the model's structure}

The contribution of the component drivers and their modules to graziers' management style were ascertained and are now presented. 


\section{$4 \quad$ Results}

Output from the model was analysed to ascertain the degree of influence of sets of factors (modules), and of individual drivers of graziers' management style. Results are presented in Table 1. Modules are listed in rank order of their influence over the final output node - representing the conservatism and sensitivity with which a grazier may manage rehabilitated mine land. Further columns indicate the influence of component drivers within each module and on the final output node.

Table 1 The influence of individual drivers and sets of drivers on model output

\begin{tabular}{|c|c|c|c|c|}
\hline Module & Individual Risk Drivers & $\begin{array}{l}\text { Proportion of } \\
\text { Influence of the } \\
\text { Whole Module } \\
\text { on the Final } \\
\text { Output Node } \\
\text { (\%) }\end{array}$ & $\begin{array}{l}\text { Proportion of } \\
\text { Individual } \\
\text { Driver's } \\
\text { Influence } \\
\text { Within Each } \\
\text { Module (\%) } \\
\end{array}$ & $\begin{array}{l}\text { Proportion of } \\
\text { Influence of } \\
\text { Individual } \\
\text { Drivers on the } \\
\text { Final Output } \\
\text { Node (\%) } \\
\end{array}$ \\
\hline \multirow{3}{*}{$\begin{array}{l}\text { Module Three: The } \\
\text { capital structure of } \\
\text { the grazing } \\
\text { business. }\end{array}$} & Equity held. & $25 \%$ & $42 \%$ & $10 \%$ \\
\hline & Property size. & & $33 \%$ & $8 \%$ \\
\hline & $\begin{array}{l}\text { Number of dependent } \\
\text { households. }\end{array}$ & & $25 \%$ & $6 \%$ \\
\hline \multirow{5}{*}{$\begin{array}{l}\text { Module Six (a): } \\
\text { Factors where } \\
\text { interventions by } \\
\text { mining companies } \\
\text { could reduce } \\
\text { effects of risk } \\
\text { drivers. }\end{array}$} & $\begin{array}{l}\text { Sufficiency of management } \\
\text { caveats. }\end{array}$ & $23 \%$ & $48 \%$ & $11 \%$ \\
\hline & $\begin{array}{l}\text { Adequacy of consultation - } \\
\text { compliance. }\end{array}$ & & $24 \%$ & $6 \%$ \\
\hline & $\begin{array}{l}\text { Adequacy of consultations - } \\
\text { 'ownership'. }\end{array}$ & & $15 \%$ & $3 \%$ \\
\hline & Perceived challenges. & & $7 \%$ & $2 \%$ \\
\hline & Perceived risks. & & $7 \%$ & $2 \%$ \\
\hline \multirow{4}{*}{$\begin{array}{l}\text { Module Six (b): } \\
\text { Indicators of } \\
\text { graziers' affective } \\
\text { motives for seeking } \\
\text { tenure. }\end{array}$} & $\begin{array}{l}\text { Graziers visualises return of } \\
\text { the land. }\end{array}$ & $17 \%$ & $50 \%$ & $8 \%$ \\
\hline & $\begin{array}{l}\text { Concern that others might } \\
\text { obtain tenure. }\end{array}$ & & $18 \%$ & $3 \%$ \\
\hline & Desire to exclude others. & & $18 \%$ & $3 \%$ \\
\hline & Affinity to the domain. & & $14 \%$ & $2 \%$ \\
\hline \multirow{4}{*}{$\begin{array}{l}\text { Module Two: } \\
\text { Within-person } \\
\text { factors. }\end{array}$} & $\begin{array}{l}\text { Attitudes to land } \\
\text { management. }\end{array}$ & $14 \%$ & $50 \%$ & $7 \%$ \\
\hline & Lifestyle values dominate. & & $25 \%$ & $3 \%$ \\
\hline & $\begin{array}{l}\text { Conservation values } \\
\text { dominate. }\end{array}$ & & $21 \%$ & $3 \%$ \\
\hline & Economic values dominate. & & $4 \%$ & $1 \%$ \\
\hline \multirow{2}{*}{$\begin{array}{l}\text { Module Four: The } \\
\text { operating structure } \\
\text { of the grazier's } \\
\text { business. }\end{array}$} & $\begin{array}{l}\text { Grazing intensity } \\
\text { traditionally practised by the } \\
\text { grazier. }\end{array}$ & $12 \%$ & $66 \%$ & $8 \%$ \\
\hline & Flexibility of operation. & & $34 \%$ & $4 \%$ \\
\hline \multirow{4}{*}{$\begin{array}{l}\text { Module Five: The } \\
\text { external } \\
\text { environment - not } \\
\text { controllable. }\end{array}$} & Occurrence of drought. & $9 \%$ & $35 \%$ & $3 \%$ \\
\hline & Interest rate levels. & & $31 \%$ & $3 \%$ \\
\hline & Cattle prices. & & $18 \%$ & $2 \%$ \\
\hline & Graziers' operating costs. & & $15 \%$ & $1 \%$ \\
\hline
\end{tabular}


Financial security as indicated by the capital structure of the grazier's business was found to exert the most influence over the style of land management graziers use if cattle grazing is the designated end use. Changes to capital structure account for $25 \%$ of the changes modelled to occur in land management style.

Actions that mining companies could take to reduce grazing risks account for a similar proportion (23\%) of risks of grazing. Possible actions include building strong trustful and respectful relationships with graziers, jointly developing any management constraints that may apply to the use of the land, and increasing the communication and ownership by graziers of the end use planning process. Such actions help build graziers' voluntary commitment to sustainable outcomes for mined land.

Where a grazier feels a strong need to regain control of the land, even if its use is not financially rewarding, the likelihood of conservative and sensitive management is affected by $17 \%$. The basis of graziers' seeking land tenure for non-financial reasons is associated with a restoration of ownership rights that may have been compulsorily acquired when mining was commenced, a desire to retain the social uniformity among landholders of the region, and a fear that new (unknown) owners of land adjoining their property may compromise the security of their assets.

Within-person characteristics (graziers' values and attitudes to land use) exert an influence of $14 \%$ over future land management style. The property's operational structure has approximately $12 \%$ influence, and the external climatic and economic environment, approximately $9 \%$.

\section{Discussion}

The research findings are potentially valuable to the industry in two situations. Table 2 summarises steps that will promote efficient use of the company's resources that are directed towards rehabilitation.

For existing rehabilitated domains where rehabilitation has been completed, output from the model can be used to support an application for progressive certification. Such modelling may support either of three positions:

1. Where risks of grazing are assessed as being too high, an alternative end use can be purposefully and transparently pursued.

2. Risks may be high, but the model may identify actions capable of reducing risks to an acceptable level.

3. Risks may be low, and grazing can be chosen. In all cases, poorly-based decisions are avoided and the goal of identifying a prudent, low-risk end use is achieved.

For future rehabilitation work, the model can be used during mine life planning processes to explicitly identify in advance those domains where grazing could reasonably be expected as an achievable end use. The likelihood of attaining that outcome can then be enhanced by attention to factors important for commercially realistic grazing. That is, instead of attempting to retro-fit design features appropriate to farming only if rehabilitation outcomes are successful, such factors could be incorporated into landscape design at an early stage. On domains where grazing is not planned, an alternative end use can be transparently and purposefully pursued. 


\begin{tabular}{|c|c|c|}
\hline \multirow[b]{2}{*}{ Recommendations } & \multicolumn{2}{|l|}{ Applicability to: } \\
\hline & $\begin{array}{l}\text { Past } \\
\text { Rehabilitation } \\
\text { Work }\end{array}$ & $\begin{array}{l}\text { New } \\
\text { Rehabilitation } \\
\text { Work }\end{array}$ \\
\hline $\begin{array}{l}\text { Purposeful and transparent commitment to specific end uses, of which } \\
\text { grazing may be one. }\end{array}$ & $*$ & $*$ \\
\hline $\begin{array}{l}\text { Avoidance of 'silo' thinking regarding end use and the pursuit of various } \\
\text { ways to capture value for the company. }\end{array}$ & * & * \\
\hline Avoidance of autonomous rehabilitation decisions at site level. & & * \\
\hline $\begin{array}{l}\text { Encouragement of existing small-scale grazing endeavours by adjusting } \\
\text { site rules designed for mining operations to accommodate efficient } \\
\text { grazing management. }\end{array}$ & $*$ & \\
\hline $\begin{array}{l}\text { Gain experience of progressive certification with grazing as the } \\
\text { designated end use - or at least establish a medium-term tenure deal } \\
\text { with a grazier - as demonstration of the company's bona fides. }\end{array}$ & $*$ & \\
\hline $\begin{array}{l}\text { Build relationships with local landholders. Genuine, one-on-one at an } \\
\text { appropriate level — senior management to senior management. }\end{array}$ & $*$ & $*$ \\
\hline $\begin{array}{l}\text { Develop land management caveats in conjunction with graziers, } \\
\text { appropriate government departments and research organisations. }\end{array}$ & * & \\
\hline
\end{tabular}

\section{Conclusions}

Best practice principles of mine closure require that planning for a site's rehabilitation and its end use be considered from the early stages of project evaluation. Legal obligations and corporate policies also require companies to plan early for site rehabilitation and to designate a sustainable end use for the site.

In the Bowen Basin of central Queensland, susceptibility of mined land to water erosion is a threat to site stability and hence to the sustainability of its end use. The level of biophysical productivity achieved at some rehabilitated sites is sufficient not only to provide vegetation protection from the erosive effects of rainfall, but also to sustain the grazing of cattle. Cattle grazing is therefore potentially a sustainable end use for mined land, and this capability has been demonstrated both theoretically and in practice. However, the way the cattle (and the land) are managed is still a critical factor influencing the sustainability of grazing. The perceived risk is that cattle farmers may over-graze the land, leaving insufficient vegetation cover to afford protection from water erosion. The way in which mined land is managed is therefore a critical factor in the sustainability of grazing as an end use.

This research investigated drivers of management decisions, focusing on the role of graziers' characteristics and circumstances on the intensity with which they use the land (the stocking rate they practise). Relationships between drivers and resulting land management style were modelled in the framework of a Bayesian Belief Network (BBN). A BBN was chosen as the modelling framework because of its ability to account explicitly for uncertainty, to utilise imprecise and multidisciplinary data, and to model scenarios.

The model improves understanding of the risks of grazing by identifying and quantifying the influence of graziers' characteristics and circumstances on their land management style. Interventions that mining companies may use to significantly reduce risks are also identified. The model thus provides an objective basis on which to assess and minimise the risks of returning mined land to grazing. The research also demonstrates the use of conditional probabilities as a productive approach to modelling in this situation, and foreshadows its value in the assessment of alternative end uses in the Bowen Basin and elsewhere. 


\section{Acknowledgements}

Support by B. Kirsch of Billiton Mitsubishi Alliance (BMA), the Australian Coal Association Research Program (ACARP), Bowen Basin graziers, and expert informants, is gratefully acknowledged.

\section{References}

Australian and New Zealand Minerals and Energy Council/Minerals Council of Australia (ANZMEC/MCA) (2000) Strategic Framework for Mine Closure, Australian and New Zealand Minerals and Energy Council/Minerals Council of Australia, $22 \mathrm{p}$.

BHP Billiton (2009) Sustainable development reports, BHP Billiton, viewed 16 April 2009, http://www.bhpbilliton.com/bb/sustainableDevelopment/reports.jsp.

BHP Billiton (2008) Sustainable Development Policy, BHP Billiton, Version 1.0, viewed 4 July 2009, http://www.bhpbilliton.com/bb/sustainableDevelopment/ourApproachToSustainability.jsp.

Bureau of Meteorology (2009) Monthly Climate Statistics for 'Emerald Post Office', Bureau of Meteorology, viewed 2 July 2009, http://www.bom.gov.au/clim_data/cdio/tables/text/IDCJCM0036_035027.csv.

Coal and Allied (2009) Reports and publications, Rio Tinto, viewed 18 April 2009, http://www.coalandallied.com.au/media/38_reports_and_publications.asp.

Cobby, G. (2007) Western Australian Regulatory Approach to Mining Approvals and Mine Closure, In Proceedings of the Second International Seminar on Mine Closure, Mine Closure 2007, A.B. Fourie, M. Tibbett, J.V. Wiertz (eds), 16-19 October 2007, Santiago, Chile, Australian Centre for Geomechanics, Perth, pp. 103-106.

Department of the Environment, Water, Heritage and the Arts (1996) Best Practice Environmental Management in Mining, Environmental Auditing, Department of the Environment, Water, Heritage and the Arts, Canberra, ACT, Australia.

EPA (2006) Guideline 18: Rehabilitation requirements for mining projects, Queensland Government (Environment Protection Agency), Brisbane.

Finucane, S.J. (2008) Thinking About the End Before You Start - Integrating Mine Closure Planning into Feasibility Studies and Environmental and Social Impact Assessment, In Proceedings of the Third International Seminar on Mine Closure, Mine Closure 2008, A.B. Fourie, M. Tibbett, I.M. Weiersbye, P. Dye (eds), 14-17 October 2008, Johannesburg, South Africa, Australian Centre for Geomechanics, Perth, pp. 171-182.

Fleury, A.M. and Copley, C. (2008) Tools for Integrated Closure Planning, In Proceedings of the Third International Seminar on Mine Closure, Mine Closure 2008, A.B. Fourie, M. Tibbett, I.M. Weiersbye, P. Dye (eds), 14-17 October 2008, Johannesburg, South Africa, Australian Centre for Geomechanics, Perth, pp. 57-67.

Friedel, M., Puckey, H., O’Malley, C., Waycott, M., Smyth, A. and Miller, G. (2006) Buffel grass: both friend and foe An evaluation of the advantages and disadvantages of Buffel grass use, and recommendations for future research, Report 17, Desert Knowledge Cooperative Research Centre, Alice Springs, Northern Territory.

Grigg, A. (2001) How much grazing? Options for rehabilitated grasslands after open cut coal mining in central Queensland, Ecological Management and Restoration, Ecological Society of Australia, Vol. 2, No. 2, pp. 151-152.

Grigg, A., Mullen, B., Byrne, T. and Shelton, M. (2006) Sustainable Grazing on Rehabilitated Lands in the Bowen Basin, Australian Coal Association Research Program Project C9038 (Stage 2) Stage 2 Final Report, Centre for Mined Land Rehabilitation, The University of Queensland.

Grigg, A., Mullen, B., Byrne, T. and Shelton, M. (2004) Stakeholder perceptions of grazing as a post-mining land use in central Queensland. A component of Australian Coal Association Research Program Project C9038 (Stage 2), Centre for Mined Land Rehabilitation, The University of Queensland, p. 12 (unpublished).

Grimshaw, S. (2007) Planning for Closure as Part of Project Approval, In Proceedings of the Second International Seminar on Mine Closure, Mine Closure 2007, A.B. Fourie, M. Tibbett, J.V. Wiertz (eds), 16-19 October 2007, Santiago, Chile, Australian Centre for Geomechanics, Perth, pp. 289-300.

International Council on Mining and Metals (ICMM) (2008) Sustainable Development Framework: 10 Principles, International Council on Mining and Metals, viewed 23 January 2009, http://www.icmm.com/ourwork/sustainable-development-framework/10-principles.

Logan, R.B., Murphy, D.P. and Beale, C.A. (2007) Mine Closure Risk and Decision Analysis, In Proceedings of the In Proceedings of the Second International Seminar on Mine Closure, Mine Closure 2007, A.B. Fourie, M. Tibbett, J.V. Wiertz (eds), 16-19 October 2007, Santiago, Chile, Australian Centre for Geomechanics, Perth, pp. 225233.

Maybery, D., Crase, L. and Gullifer, C. (2005), Categorising farming values as economic, conservation and lifestyle, Journal of Economic Psychology, Vol. 26, No. 1, pp. 59-72.

Natural Resources and Minerals (NRM) (2004) Soil Condition: Soil Properties - Soil erosion by water, Australian Government viewed 11 August 2005, http://www.nrm.gov.au/monitoring/indicators/soil/water.html. 
Rio Tinto (2004) Closure Standard, Rio Tinto, viewed 15 April 2008, http://www.riotinto.com/documents/Closure Standard.pdf.

Robertson, A. and Shaw, S. (2006) Custodial Transfer, EnviroMine, viewed 14 May 2007, http://technology.infomine.com/enviromine/issues/cls_custod.html.

Slaughter, G.J. (2002) The relationship between viable financial performance and sustainable land management practices on grazing enterprises in the eastern mulgalands of south west Queensland, The University of Queensland, Brisbane, Queensland, PhD thesis (unpublished).

The State of Queensland (2007) State of the Environment Queensland 2007, Queensland Government (Environment Protection Agency), viewed 14 Oct 2008, http://www.epa.qld.gov.au/environmental_management/state_of_the environment/state_of the environment_queensland_2007/.

The State of Queensland (2003) State of the Environment Queensland 2003, Queensland Government (Environment Protection Agency), viewed 20 June 2006, http://www.epa.qld.gov.au/environmental_management/state_of_ the_environment/state_of_the_environment_2003/.

The State of Queensland (1999) State of the Environment Queensland 1999, Queensland Government (Environment Protection Agency), viewed 20 June 2006, http://www.epa.qld.gov.au/environmental_management/ state_of the environment/state_of the environment_1999/.

The State of Queensland (1994) Environmental Protection Act (Qld), Office of the Queensland Parliamentary Counsel, Brisbane, Queensland.

The State of Queensland (1989) Mineral Resources Act (Qld), Office of the Queensland Parliamentary Counsel, Brisbane, Queensland.

The State of Queensland (1968) Central Queensland Coal Associates Agreement Act (Qld), Office of the Queensland Parliamentary Counsel, Brisbane, Queensland.

Thiess Pty Ltd (2005) Environmental Policy, Thiess Pty Ltd, viewed 14 May 2006, http://www.thiess.com.au/tms/groups/public/documents/information/027820.pdf.

Welsh, D.R. (2007) Mine Closure - A Regulator's Guide to the Things that Matter, In Proceedings of the Second International Seminar on Mine Closure, Mine Closure 2007, A.B. Fourie, M. Tibbett, J.V. Wiertz (eds), 16-19 October 2007, Santiago, Chile, Australian Centre for Geomechanics, Perth, pp. 69-77.

Welsh, D.R., Bianco, A. and Roe, P. (2007) A Risk Assessment Approach for Comparing Mine Rehabilitation and Closure Options at Coal Mines in Central Queensland, Australia, In Proceedings of the Second International Seminar on Mine Closure, Mine Closure 2007, A.B. Fourie, M. Tibbett, J.V. Wiertz (eds), 16-19 October 2007, Santiago, Chile, Australian Centre for Geomechanics, Perth, pp. 167-178.

Williams, D.J. (2001) Risk assessment of Bowen Basin spoil rehabilitation: Final Report, Department of Civil Engineering, The University of Queensland, Brisbane, Queensland.

Xstrata (2008) Sustainability, biodiversity, conservation and rehabilitation, Xstrata, viewed 23 October 2008 , http://www.xstrata.com/sustainability/environment/biodiversity. 